\title{
The State of the Monetarist Debate
}

\author{
by LEONALL C. ANDERSEN
}

The following paper was presented last spring as part of a series of public lectures held at the following universities: The Ohio State University; University of California at Los Angeles; and University of Southern California.

As indicated by the title, the purpose of the paper is to discuss those issues which appear to have divided economists into two camps: monetarist and post-Keynesian. To further this objective, two discussants of opposing viewpoints were invited to comment on the Andersen presentation. Professor Lawrence R. Klein of the Wharton School of Finance, University of Pennsylvania, provides comments from a post-Keynesian point of view. Professor Karl Brunner of the University of Rochester discusses the issues from a monetarist position.

Fon

OR OVER thirtynfive years there has been continuing debate between two prominent schools of economic thought. In recent years these two schools have been characterized by the labels "monetarist" and "post-Keynesian" economics. Some major participants on the monetarist side are professors Karl Brunner, Milton Friedman, and Allan Meltzer. The post-Keynesian side is represented by such academic economists as Lawrence Klein, Franco Modigliani, Paul Samuelson, and James Tobin.

The debate has been ongoing since the publication of Keynes' General Theory in the mid-1930s. It became particularly heated in the late 1940s, and in the 1950s post-Keynesian views dominated macro-economic theory and economic stabilization policy. The debate was reopened in the late $1950 \mathrm{~s}$, and beginning in the mid-1960s the monetarist view began to be recognized as a serious challenge to post-Keynesian economics.

The debate has ranged over three major fields of interest to economists. These are macro-economic theory, economic stabilization policy, and economic research methodology. My remarks today will concentrate primarily on the stabilization aspects of the debate, although $I$ will of necessity bring in some discussion of the other two.

For purposes of this discussion, I will focus on six topics of the economic stabilization aspect of the debate. These are: the impact of monetary actions, the impact of fiscal actions, the trade-off between inflation and unemployment, the factors infuencing interest rates, the degree of stability inherent in the economy, and the appropriate time horizon for stabilization policy. In discussing each of these topics, I will first summarize the contending views in the last half of the 1960s. Then, I will summarize the progress made in reconciling these views up to the present time.

I want to point out that my analysis of these topics is from the point of view of an active participant on the monetarist side of the debate. The analysis reflects my view of the debate and may not agree, in all aspects, with the views of other participants - monetarists or post-Keynesians. In addition, for purposes of this discussion, I will contrast two polar positions. It must be recognized, however, that there are many who consider themselves to be in some middle-of-theroad position on many of the issues.

\section{THE IMPACT OF MONEY}

\section{A Post-Reynesian View}

Let us now examine the first issue - the role of money as an important driving force in the economy. Paul Samuelson, in commenting on the debate, has provided an excellent summary of the post-Keynesian view regarding money. ${ }^{1}$

As a limit upon the stimulus stemming from money creation by orthodox open-market operations, must be reckoned the fact that as the central bank pumps new money into the system, it is in return taking from the system an almost equal quantum of money substitutes in the form of government securities.

What needs to be stressed is the fact that one cannot expect money created by this process alone... to have at all the same functional relationship to the level of the GNP and of the price index as could be the case for money created by gold mining or money created by the printing press of national governments or the Fed and used to finance public expenditures in excess of tax receipts. ${ }^{2}$

1Paul A. Samuelson, "Reflections on the Merits and Demerits of Monetarism," in Isstses in Fiscal and Monetary Policy: The Eclectic Economist Views the Controversy, ed. James J. Diamond (DePaul University, 1971), pp 7-21.

2lbid., pp. 8-9. 
Samuelson continues this analysis by pointing out that money creation in today's economy does not necessarily reflect creation of wealth, and thereby exerts no direct influence on aggregate demand. Creation of money, however, does change interest rates which in turn influence aggregate demand. He then points out that research of the late 1930s and $1940 \mathrm{~s}$ led economists to reject money because interest rates were found to exert little influence on aggregate demand.

Samuelson then presents his view of recent economic history by stating that Pigou's real balance effect of money on consumption served to reconcile the deep cleavage between neo-classical theory and the Keynesian revolution. He then contends that

... by the 1950's and 1960's an accumulating body of analysis and data had led to a strong belief that open-market and discount operations by the central bank could have pronounced macroeconomic effects upon investment and consumption spending in the succeeding several months and quarters. ${ }^{3}$

Despite this strong contention regarding the influence of monetary actions, post-Keynesian analysis, until recently, has persisted in denigrating the influence of money because of the rather weak, or long delayed, response of aggregate demand to changes in interest rates. Econometric models continued to stress the interest rate channel and shied away from incorporating any influence of real money balances. For example, when simulations of the original KleinGoldberger model of the late 1950 s showed that the real balance effect swamped all other influences, the monetary sector was dropped from the model because such a result was deemed "unrealistic" and "implausible."

\section{Aonetarist Vien}

Now for the other side of this issue. The monetarists contend that changes in money exert a strong force on aggregate demand (measured in nominal terms), the price level, and output. In determining the impact of money, it is further contended that a distinction must be made between nominal and real economic magnitudes and between the short run and the long run.

Changes in the trend growth of money are considered the dominant, not the exclusive, determinant of the trend of nominal GNP and the price level. Long-

Ilbid, p. 12 .

${ }^{4}$ Arthur S. Goldberger, Impact Multipliers and Dunamic Properties of the Klein-Goldberger Model (Amsterdam: NorthHolland Publishing Company, 1959), pp. 84-85. run movements in output are little influenced by changes in the growth rate of money. Trend movements in output are essentially determined by the growth of such factors as the labor force, natural resources, capital stock, and technology. In the short run, however, changes in the trend growth of money or pronounced variations around a given trend exert a significant, but temporary, impact on output. The timing and magnitude of such impact depends on initial conditions at the time of a change in money growth. Two major indicators of initial conditions are the level of resource utilization and the expected rate of inflation.

Monetarists do not maintain, as asserted by many post-Keynesians, that money is the only influence on either nominal or real economic magnitudes. Other factors which exert a significant influence are factors which change the demand for money, productivity, and factor endowment. There is even room in this analysis for Keynes" "animal spirits" on the part of businessmen. The key proposition is that changes in money dominate other short-run influences on output and other long-run influences on the price level and nominal aggregate demand. I will have more to say later in this regard.

\section{Recent Developments in the Debate}

An integral part of the debate regarding the influence of money on economic activity is the different views held regarding the economic function of money. Some who denigrate the importance of money point out that it is one asset which carries no monetary yield. Others stress that money in today's economy is not wealth and conclude that changes in money have little direct influence on spending decisions. Some post-Keynesians view money as only one of a virtually continuing spectrum of financial assets and thus believe it to be of only secondary importance.

A further argument advanced about the role of money has been based upon the lack of synchronization between transactors' receipts and expenditures. In such a case, it is desirable for market participants to hold an inventory of money balances. This argument can be used to develop a model which delegates a powerful role for money in influencing economic activity. The post-Keynesians, however, have not produced such a model.

On the other side of the debate, empirical evidence has been presented to support the view that money matters to a considerable degree; but, until recently, little attention has been given to producing a rigorous 
analysis of the role that money plays in a market economy. In recent years, the view has been growing that money does have an extremely important influence because it is the asset used by society which minimizes the economic costs associated with collecting market information and conducting market transactions.

Brunner and Meltzer, using this cost of information and transactions argument, have presented an extended analysis of the emergence of money in a market economy. Their view of the role of money is the following:

Our analysis extends the theory of exchange to in. clude the cost of acquiring information about market arrangements, relative prices, or exchange ratios. Individuals search for those sequences of transactions, called transaction chains, that minimize the cost of acquiring information and transacting. The use of assets with peculiar technical properties and low marginal cost of acquiring information reduces these costs. Money is such an asset, and the private and social productivity of money are a direct consequence of the saving in resources that the use of money permits and of the extension of the market system that occurs because of the reduction in the cost of making exchanges.

Thus, money as a medium of exchange, as a transaction dominating asset, results from the opportunities offered by the distribution of incomplete information and the search by potential transactors to develop transaction chains that save resources. ${ }^{\text {t }}$

What has been the outcome of the debate thus far on the issue of the role of money in economic stabiliza tion? There is no doubt that money has been assigned a more prominent role in recent years, but not to the extent advocated by monetarists. Econometric model builders have begun to give greater recognition to money. For example, Lawrence Klein has reported that the Wharton model now has a real money balance effect and that now the model predicts better. Simulations of the MIT-FRB model, which had Franco Modigliani as one of the principal architects, demonstrate the long-run properties of money as stressed by monetarists; namely, changes in money, in the long run, influence mainly the price level.

In recent years, money has also received more attention in the conduct of economic stabilization. For years, post-Keynesians recommended that market interest rates be the strategic variable to be controlled in stabilization efforts. Policymakers tended to follow

\footnotetext{
5Karl Brumer and Alar H. Meltzer, "The Uses of Money: Money in the Theory of an Exchange Economy," The American Economic Review (December 1971), p. 804. Ibid., p. 793.
}

this recommendation almost exclusively until late in the $1960 \mathrm{~s}$.

Attention has gradually shifted in recent years toward more emphasis on money and less on interest rates. From 1951 to 1966, the Federal Open Market Committee stressed only market interest rates and other measures of money market conditions. From 1966 to 1970 , money or other monetary aggregates served as a minor constraint on actions regarding interest rates. In 1971, interest rates were manipulated in an attempt to produce desired movements in money. Finally in 1972, changes in reserves available for private deposits were formally set forth as a means of controlling money. Such actions, however, were constrained to a considerable degree by interest rate considerations. Since 1969 the President's Council of Economic Advisers has recommended changes in money and credit as a better guide for monetary actions than market interest rates.

Although the debate regarding money is less acrimonious today, some important areas of contention remain. A foremost one is in regard to the speed of response of output, prices, and nominal GNP to a change in money. Monetarist theories and empirical studies point to a relatively quick, but short-lived, response of output to a change in money growth, with a longer time period required for prices to respond fully. Post-Keynesian econometric models, on the other hand, produce an impact of money changes only over a much longer period.

Many economists now agree with the proposition of monetarists that the long-run influence of money is only on the price level, with no lasting impact on output. Some, however, have distorted the monetarist view by asserting that monetarists believe that these long-run propositions also hold in the short run. For example, Governor Andrew Brimmer of the Federal Reserve System, in commenting last year on the debate, concluded that ". . there really is no difference between modern monetarists and modern Keynesians with respect to the long-run implications of their theory." But, he then asserts, "Monetarists appear to argue that the reactions expected in the long-run can also be expected to hold even in the short-run." This is simply incorrect.

Another major point of contention is the nature of the monetary transmission mechanism. Post-Keyne-

\footnotetext{
TAndrew F. Brimmer, "Monetarist Criticism and the Conduct of Flexible Monetary Policy in the United States" (Paper presented at the Institute of Economics and Statistics, Oxford University, Oxford, England, April 24, 1972), p. 8.

slbid., p. 13.
} 
sians have advanced their views of this mechanism and have buit empirical models based on their views. On the other hand, monetarists, until recently, have not developed such empirical models. Brunner and Meltzer have now developed a theoretical model of the transmission mechanism, which is based on relative price theory, and plan to make empirical tests of its implications. At the Federal Reserve Bank of St. Louis, we are in the process of spelling out our theory of the channels by which changes in money influence nominal GNP, the price level, and output. Along with the theoretical work, we are attempting to estimate the parameters of these channels of monetary influence.

\section{THE IMPACT OF FISCAL ACTIONS}

Let us now turn our attention to the second issue the role of fiscal actions in economic stabilization. The generally accepted view is that changes in Federal Government expenditures and tax rates exert a strong and rapid force on aggregate demand. Most monetarists, but not all, contend that the influence of such actions is transitory.

Post-Keynesians advance three main arguments for the primacy of fiscal actions. Increases in Govemment spending add directly to aggregate demand, and reductions in tax rates increase disposable income, thereby increasing aggregate demand. Both of these actions are held to have a multiplier effect. Government borrowing adds to wealth which increases spending. With a constant money stock, higher interest rates result which, in turn, reduce the quantity of money demanded. To the extent that the velocity of circulation increases, there is a fiscal impact on aggregate demand.

Monetarists point out empirical evidence that the Govemment expenditure multiplier, with a constant money stock, is positive for a few quarters, but in the long run it is zero. The argument frequently advanced in support of such a response is the so-called "crowd. ing-out" effect. In the absence of accompanying monetary expansion, Government expenditures must be financed by taxes or borrowing from the public. In either case, command over resources is transferred from the private sector to the Government, with the result that there is no net addition to purchases. Only in the case of a deficit financed by the monetary sector does Government spending exert more than a short-run positive influence on aggregate demand.

Such a response carries an implication opposite to that postulated by Samuelson regarding money. Ac- cording to Samuelson, money has an important influence only when it is created to finance Government expenditures. Monetarists contend that Government expenditures increase aggregate demand permanently only if they are continually financed by creating money. Monetarists recognize, however, that Government spending financed by borrowing can have an important indirect effect on spending because deficits tend to induce central banks to increase money.

The fiscal aspect of the debate is far from being resolved. The post-Keynesian view has continued to be the dominant one in both macro-economic theory and in stabilization policy. Monetarists, however, have caused both theorists and model builders once again to take specifically into consideration the financing aspects of Government spending. These financing aspects, for the most part, had been dropped from both these endeavors in the early 1950 s when the crude fiscal multiplier analysis came into vogue.

The general rejection of the challenging view has been mainly the result of its failure to specify the transmission mechanism whereby crowding-out occurs. Economists such as Brunner and Meltzer and Carl Christ have developed theoretical structures in which the Government's budget constraint plays an important role. Such structures will be useful in identifying the conditions under which crowding-out occurs. Monetarists continue to be skeptical regarding the influence of fiscal actions when such influence is measured without due regard given to financing considerations.

One final point. Just as in the case of the role of money, the debate over fiscal actions may be largely one of timing. Both the MIT-FRB model and the Data Resources model, which are built along post" Keynesian lines, have a zero Government spending multiplier with regard to real output. But this result takes a fairly long period of time to accrue. On the other hand, monetarists generally believe this same result occurs within a much shorter time interval.

\section{TIIE TNELATION-UNEMPLOYNENT TRADE-OFE}

I am sure you are familiar with the argument that an economy must accept a high unemployment rate in order to have a low rate of inflation, or that a low unemployment rate can only be achieved at the cost of a high rate of inflation. Monetarists, as well as many other economists, reject this argument, contending that in the long run the "normal" or "natural" 
unemployment rate will eventually evolve regardless of the rate of inflation.

With regard to this issue, post-Keynesians have generally relied more on empirical evidence, while proponents of the alternative view have relied more on theoretical arguments. This is an interesting reversal of approaches from those used in the two previous issues.

In simple form, most empirical studies of the inflation-unemployment trade-off have proceeded in the following manner. The price level is said to be a markup of labor costs, which depend on wage rates and productivity. Wage rate changes, in turn, are postulated to be negatively related to the degree of slack in the labor market, measured by the unemployment rate. Empirical studies have found it possible to measure such relationships; thus, post-Keynesians conclude that the above mentioned trade-off exists.

Monetarists have developed mostly theoretical arguments in support of the "no trade-off" proposition. It is not denied that a short-run trademoff exists, but it is denied that such a trade-off exists in the long run. The crucial consideration involves the formation of price expectations, a variable generally neglected umtil recently in post-Keynesian analysis.

I will not go through this very complicated analysis. Instead, I will merely point out the conclusion that when prices rise at a constant rate, and if the expected rate of price change is the same, the unemployment rate will be at its normal rate and will remain there until a shock occurs. This normal un employment rate is determined by such factors as cost of labor market information, labor mobility, job discrimination, and laws and organizations which impede the free functioning of the labor market.

This trade-off issue is far from being settled. It is quite generally agreed that the crucial consideration is the manner in which price expectations are formed. No trade-off exists unless price expectations are formed in such a manner that in the long run expected price changes fully reflect actual price changes. Empirical evidence presented to date has proven to be inconclusive - there is support for both sides of the debate.

In one respect, some post-Keynesians have moved closer, but not completely, to accepting the no tradeoff view. Simulations of several prominent econometric models give results which show a very sharp trade-off relationship (that is, a large change in inflation, but a very small change in the unemployment rate) instead of the comparatively less sharp tradeoff suggested in earlier empirical studies.

Both sides, however, are in quite general agreement regarding the desirability of actions to improve the functioning of our labor and commodity markets. Be there no trade-off, a sharp one, or a relatively mild one, it is agreed that less restricted markets would tend to reduce the rate of unemployment associated with any given rate of inflation.

\section{FACTORS INTLUENCNNG MARERT WTIERST RATES}

The next issue in the debate which I will discuss is the one regarding the factors influencing market interest rates. This issue has basically revolved around the distinction between real and nominal interest rates. Another important point of difference has been the market in which interest rates are determined.

Post-Keynesians have advanced the view that the short-term interest rate is basically determined by the demand for and the supply of money balances in what they call the "money market." The short-term rate is then postulated to influence the long-term via a term structure relationship. Finally, there is a response of interest-sensitive components of aggregate demand, followed by an aggregate demand feedback on the interest rate.

For years, the price level was held constant in a large body of post-Keynesian analyses, with the result that all variables were in real terms, including interest rates. Monetarists have revived the much earlier view of Irving Fisher regarding interest rates. They focus on the nominal rate of interest, which is determined by factors influencing the real rate of interest, and takes into consideration the expected rate of inflation. According to this analysis, the real interest rate is determined by a multiplicity of factors traditionally summarized in the phrase "productivity and thrift." The nominal interest rate, in equilibrium, is equal to the real interest rate plus the expected rate of inflation.

This analysis has led monetarists to summarize the factors which influence market interest rates as the liquidity or money effect, the output effect, and the expected rate of inflation. An increase in the rate of money growth first decreases market interest rates, but then output rises in response to the faster money growth. This results in an increase in the demand for credit and interest rates rise. Finally, inflation increases, and, to the extent that this is reflected in 
expectations of inflation, an inflation premium is incorporated into market interest rates.

Experience with inflation since the mid.1960s has led most economists to incorporate price expectations into their interest rate analysis. Econometric model builders found it necessary to introduce this factor because, prior to doing so, their models had forecast interest rate movements rather badly in the inflationary period of the late 1960s. Outside of this change, however, their interest rate mechanism has remained essentially as outlined earlier.

A sharp controversy has existed regarding the appropriate role of interest rates in monetary policy. The conventional view has stressed interest rates as the key variable to be manipulated by the central bank in seeking to achieve its stabilization goals. High and rising interest rates have been interpreted as indicating monetary restraint. The opposing view insists that the central bank has very imperfect control over market interest rates in any period other than a very short one, and that a prolonged period of high and rising rates indicates monetary ease.

Even though some policy advisers, such as the Council of Economic Advisers and some members of the Federal Open Market Committee, have accepted the view that interest rates contain a price expectations component, interest rates still play an important role in stabilization policy. In addition, there has been almost a complete lack of understanding on the part of Congress in both regarding the modern view of interest rates and in applying this view to stabilization policy prescriptions.

\section{DEGRER OF MNHERENT ECONOMIC STABILITY}

I now turn to the next issue - the dispute regarding the monetarist contention that the economy is inherently stable. Post-Keynesians contend otherwise. Samuelson has summarized a few factors which he believes affect money GNP even if money is held constant:

(1) ... any significant changes in thriftiness and the propensity to consume . . . (2) . . an exogenous burst of investment opportunities or animal spirits. ..."

The alternative view does not deny that such factors exert a significant influence on GNP, output, and the price level. But it does challenge the conventional

\footnotetext{
"Samuelson, "Reflections on the Merits and Demerits of Mone-
} tarism," p. 7 . view that these factors lead necessarily to recurring fluctuations in output and prices which are of a cyclical nature or that there does not exist a self-correction mechanism. Monetarists contend that our economic system is such that disturbing forces, including even changes in money growth, are rather rapidly absorbed and that output will naturally revert to its long-run growth path following a disturbance.

Little empirical evidence has been produced in support of either view. Post-Keynesians offer simulations of the response of their models to shocks, while the challengers have appealed more to casual empiricism. Moreover, monetarists have not been convinced by post-Keynesian evidence which does not involve holding the growth of money constant.

This issue is also far from being resolved, but one significant step has been taken toward resolution. There is quite general agreement that the role of price expectations is very important. One crucial condition necessary to yield monetarists' results is that the current rate of inflation should respond to the expected rate of inflation, however the expectation is formed, with a coefficient of one.

As in the case of several of the other issues in the debate, the central point of contention of the inherent stability issue appears to be a matter of timing. Several econometric models built along post-Keynesian lines show, by simulation experiments, that shocks are absorbed over a fairly long period of time and do not produce cycles. On the other hand, monetarists postulate a shorter period for adjustment.

\section{APPROPRATE TME HORMON FOR STABILZATION POLIOV}

Let us now turn to the final issue - the appropriate time horizon for stabilization policy. Post-Keynesians, with their view that the economy is basically unstable, have advocated very active stabilization actions in the short run. Even if a disturbance is absorbed, the time interval is considered to be so long that economic welfare will be greatly reduced if short-run stabilization actions are not taken. Some have expressed the belief that the economy can be turned around on a dime; therefore, in the case of high unemployment, stimulus can be applied until inflation rears its ugly head and then restraint can be applied to curb inflation. The term "fine-tuning" has been applied to this view. Since they hold that fiscal actions are powerful and have a relatively quick effect, and that changes in money have a very slow effect, the former tool of economic stabilization is preferred. 
Monetarists, on the other hand, prefer a relatively stable growth of money over fairly long intervals of time. This position is based on the view that changes in money exert a strong, short-run effect on output, but little influence in the longer run. It is also based on the belief that the economy is inherently stable, thereby requiring no off-setting actions. Furthermore, it is contended that short-run stabilization actions have, in the past, been exercised in such a manner as to create economic instability, and thereby have reduced economic welfare.

This issue is far from being resolved, if it ever can be, because it involves one's notion of economic welfare. It will persist even if there is conclusive evidence of a short-run, but short-lived impact of stabilization actions on output and employment and a long-run impact on the price level.

According to Robert Solow, a prominent postKeynesian,

... there is a trade-off between the speed of price increase and the real state of the economy. It is less favorable in the long run than it is at first. It may not be 'permanent'; but it lasts long enough for me. ${ }^{10}$

Monetarists contend, on the other hand, that failure to take into consideration the long-run price level implications of stabilization actions in seeking short-run output and employment objectives seriously threatens economic welfare because the long run may very well be much shorter than usually believed. If such is the case, stabilization actions based on Keynes' dictum, "In the long-run we are all dead," may lead to a serious loss of economic welfare for those living today.

\section{PRESENT STATE OF THE DERATE}

I will now conclude by summarizing the changes in views regarding economic stabilization that have occurred over recent years. Then, I will present my views regarding some steps which are needed to be taken if the debate is to be resolved.

I believe that most observers will agree that money is now receiving more attention in economic theory, econometric model building, and stabilization policy than it did just five years ago. In addition, greater consideration is given to finaneing considerations in discussions regarding the influence of fiscal actions.

10Robert M. Solow, Price Expectations and the Behavior of the Price Letel (Manchester, England: Manchester University Press, 1969), p. 17.
The influence of price expectations on market interest rates is almost universally accepted, and the primacy of interest rates as a tool of economic stabilization has been seriously challenged. Although the stable monetary growth rule has not been generally accepted, there is a quite general acceptance of the proposition that money growth should be less variable than in the $1950 \mathrm{~s}$ and $1960 \mathrm{~s}$. The proposition that inflation is primarily a monetary phenomenon, however, has not generally been accepted in stabilization policy.

Two main developments are desirable if this debate is to be resolved. The first involves monetarists and the second, post-Keynesians. Monetarists must spell out, in greater detail than up to now, the channels by which money influences nominal GNP, the price level, and cutput. Lawrence Klein, in commenting on the Wharton model and the academic version of the MIT-FRB model, has laid down this challenge to the monetarists:

Each combines fiscal with monetary analysis; each has the usual kind of fiscal multiplier; each can measure up to any purely monetarist model yet conceived as far as accuracy of performance is concerned; and each is explicit about the channels of monetary influence in a structural way. They stand as challenges to the monetarist points of view. ${ }^{11}$

As I mentioned several times, monetarists are rising to this challenge. However, if the debate is to be resolved, post-Keynesians must be willing to examine a different approach to macro-economics from their own and to consider different types of evidence. Some monetarists have rejected the traditional static IS-LM paradigm as an adequate framework for presenting their views. They are investigating altematives based on relative price theory. Furthermore, they believe that explicitly dynamic analysis will be more useful than static analysis. Costs of information, adjustment, and transactions play a central role in this theorizing. With regard to evidence, the testing of simple hypotheses is deemed to be more useful than the building of elaborate structural models.

In conclusion, I am heartened that progress has been made in recent years in delineating the main issues of the debate and in resolving some of them. Moreover, the debate is less acrimonious than earlier. It is my expectation that great strides will be made in resolving the remaining issues in the near future.

\footnotetext{
${ }^{11}$ Lawrence R. Klein, "Empirical Evidence on Fiscal and Monetary Models," in Isstes in Fiscal and Monetary Policy: The Eclectic Economist Views The Controversy, p. 49.
} 